\title{
EKSISTENSI PEMUDA THERAVADA INDONESIA (PATRIA) KABUPATEN TEMANGGUNG DALAM MEMPERTAHANKAN KEYAKINAN REMAJA BUDDHIS
}

\author{
Oleh: \\ Frizcorian Bodhi Pratama ${ }^{1}$ \\ Niken Wardani, S.H., M.Pd.B. ${ }^{2}$ \\ Marjianto, S.Pd., M.Si. ${ }^{3}$
}

\begin{abstract}
ABSTRAK
Tujuan dalam penelitian ini adalah untuk mendeskripsikan keberadaan Patria Kabupaten Temanggung dalam mempertahankan keyakinan remaja Buddhis. Kurangnya keyakinan remaja Buddhis di wilayah Temanggung menjadi alasan peneliti untuk melakukan penelitian tentang Eksistensi Pemuda Theravada (Patria) Kabupaten Temanggung dalam Mempertahankan Keyakinan Remaja Buddhis.

Penelitian ini menggunakan metode penelitian kualitatif deskriptif. Waktu penelitian ini dilakukan pada bulan Juli sampai dengan bulan Agustus. Teknik pengumpulan data menggunakan wawancara, observasi dan dokumentasi. Sedangkan teknik untuk memeriksa keabsahan data, yaitu dengan menggunakan teknik triangulasi.

Hasil penelitian menunjukkan Eksistensi Pemuda Theravada Indonesia (Patria) Kabupaten Temanggung dalam Mempertahankan Keyakinan Remaja Buddhis belum maksimal, faktanya banyak remaja Buddhis yang malas pergi ke vihara, mengikuti kegiatan agama dan Patria. Sedangakan faktor yang mempengaruhi yaitu, niat (Cettana), semangat (Viriya), dan kesadaran (Sati). Hal ini menyebabkan keyakinan remaja Buddhis pada Tri Ratna rendah, sehingga akan berdampak pada perpindahan agama.
\end{abstract}

Kata kunci: Eksistensi Patria, Keyakinan remaja Buddhis.

\begin{abstract}
The purpose of this study is to describe the existence of the Theravada youth (Patria) at Temanggung Regency in maintaining the Buddhist youth belief. The lack of Buddhists belief in the Temanggung area is one the reasons for the researcher to conduct a research about the Existence of the Theravada Youth (Patria) at Temanggung Regency in maintaining Buddhist youth belief.

This study is a descriptive qualitative research method. This research is conducted from July to August. Data collection techniques are interviews, observation and documentation. While the technique for the validity test is triangulation technique.

The results of the study show that the existence of the Theravada youth (Patria) at Temanggung regency in maintaining Buddhist youth beliefs has not been maximized yet, in fact many Buddhist teenagers are reluctant to go to the monastery and to follow religious and PATRIA activities. Meanwhile, the influencing factors are intention (Cettana), enthusiasm (Viriya), and awareness (Sati). These cause the belief of Buddhist youth in Tri Ratna is getting worst, so that many teenagers change their religion or their belief.
\end{abstract}

Keywords: Patria Existence, Buddhist Teen Belief.

\footnotetext{
${ }^{1}$ Dharmadutta STABN Raden Wijaya, email: frizco94@gmail.com

${ }^{2}$ Dosen STABN Raden Wijaya, email: nikenwardhani@ymail.com

${ }^{3}$ Dosen STABN Raden Wijaya, email: antonmarjianto@gmail.com
} 


\section{PENDAHULUAN}

Manusia adalah makhluk sosial. Dalam hidupnya manusia mempunyai ketidakterbatasan kebutuhan dan keterbatasan kemampuanya untuk memenuhi kebutuhannya secara individu. Kondisi tersebut menghadapkan manusia untuk hidup berorganisasi. Hal ini didukung dengan karakteristik manusia sebagai makhluk sosial yang tidak memungkinkan hidup wajar tanpa berorganisasi. Pada prinsipnya, organisasi adalah sekelompok orang yang bekerja sama untuk mencapai tujuan bersama, dengan kesepakatan dan kepemimpinan bersama, Widya (2010: p.1). Sehingga organisasi dibentuk dengan orientasi dan tujuan yang relatif sama yakni berhimpun dan berusaha untuk mencapai tujuan yang ditetapkan. Fahmi (2013: pp.1-2) menyatakan bahwa organisasi merupakan sebuah sistem yang terdiri dari sekumpulan individu terhadap pembagian kerja kelompok dalam rangka mewujudkan tujuan yang telah diciptakan secara sistematis dan struktural. Perbedaan tujuan yang menjadi target yang akan dicapai merupakan salah satu sebab terbentuknya banyak organisasi. Salah satu organisasi kepemudaan yang terdapat di Indonesia adalah Pemuda Theravada Indonesia (Patria). Pemuda Theravada Indonesia (Patria) yaitu sebuah organisasi sosial-keagamaan Buddhis Theravada Indonesia dengan visi yaitu aktif melahirkan generasi muda yang memiliki kemoralan, sukses dan mampu mandiri dalam kehidupan bermasyarakat dan bernegara. Partisipasi Pemuda Theravada Indonesia (Patria) bersifat pengabdian tanpa pamrih dan bersama-sama dengan Keluarga Buddhis Theravada Indonesia (KBTI) mewartakan Buddha Dhamma.
Visi Pemuda Theravada Indonesia (Patria) mendeskripsikan bahwa Pemuda Theravada Indonesia (Patria) mempunyai peran dalam membentuk generasi muda Buddhis yang mampu bertindak mandiri dan dapat memiliki moral serta sukses dalam kehidupan bermasyarakat atau berorganisasi. Keberadaan atau eksistensi Pemuda Theravada Indonesia (Patria) sangat dibutuhkan oleh remaja Buddhis guna membantu remaja Buddhis pada umumnya dan umat Buddha pada khususnya dalam meningkatkan keyakinan dan mempertahankan ajaran Buddha Dhamma di masyarakat. Sehingga, Pemuda Theravada Indonesia (Patria) seyogyanya mampu mempertahankan keyakinanya serta dapat meningkatkan keyakinan remaja Buddhis, karena peran Pemuda Theravada Indonesia (Patria) dapat membantu perkembangan dan kemajuan remajan Buddhis.

Berdasarkan hasil wawancara yang dilakukan oleh peneliti dengan saudara Wahyudi sebagai ketua Pemuda Theravada Indonesia (Patria) Kabupaten Temanggung pada tanggal 5 Februari 2018 diperoleh informasi bahwa eksistensi Pemuda Theravada Indonesia (Patria) belum maksimal. Kurang maksimalnya Pemuda Theravada Indonesia (Patria) di Kabupaten Temanggung tersebut dikarenakan kurangnya kesadaran pada remaja Buddhis untuk mengikuti pertemuanpertemuan organisasi Pemuda Theravada Indonesia (Patria) se-Kabupaten Temanggung. Ketua Pemuda Theravada Indonesia (Patria) Kabupaten Temanggung juga mengharapkan adanya bantuan Pemuda Theravada Indonesia (Patria) dari daerah lain untuk membantu meningkatkan keaktifan remaja Buddhis di wilayah Kabupaten Temanggung. 
Fakta lain yang terjadi di masyarakat Buddhis khususnya di Kabupaten Temanggung diperoleh dari wawancara yang peneliti lakukan dengan beberapa remaja Buddhis di wilayah Kabupaten Temanggung pada tanggal 8 Februari 2018, diperoleh informasi bahwa secara kualitas mengalami banyak penurunan. Informasi lain yang didapat adalah terdapat empat generasi Buddhis di Dusun Pendem Kecamatan Kaloran Kabupaten Temanggung yang berpindah agama yang disebabkan oleh pernikahan. Menurut informan (Y) hal ini terjadi dikarenakan rendahnya tingkat kesadaran remaja Buddhis dalam mempertahankan keyakinanya sehingga banyak remaja atau umat Buddha yang melakukan perkawinan dengan pasangan yang berbeda keyakinan dan memutuskan untuk pindah agama. Sehingga, kondisi demikian menjadi sebuah keprihatinan bagi umat Buddha di wilayah Kabupaten Temanggung.

Umat Buddha yang merupakan umat minoritas, seyogyanya keyakinan remaja atau umat harus diperkuat. Namun pada kenyataanya yang terjadi di lapangan remaja atau umat Buddha belum memiliki kesadaran untuk mempertahankan keyakinanya. Secara psikologis pemuda Buddhis kurang percaya diri karena jumlahnya yang sedikit, kurang mendapatkan perhatian atau pembinaaan dari pihak yang berkewajiban misalnya dari para penyuluh PNS atau non PNS, sehingga hal ini akan berdampak pada menurunnya tingkat keyakinan remaja atau umat Buddha.

Berdasarkan fakta tersebut sangat dibutuhkan eksistensi Patria dalam mempertahankan keyakinan remaja Buddhis pada khususnya dan umat Buddha pada umumnya. Zaenal (2007: p.16) menjelaskan bahwa:
"Eksistensi adalah suatu proses yang dinamis, suatu, menjadi atau mengada. Ini sesuai dengan asal kata eksistensi itu sendiri, yakni eksistere, yang artinya keluar dari, melampaui atau mengatasi. Jadi eksistensi tidak bersifat kaku dan terhenti, melainkan lentur atau kenyal dan mengalami perkembangan atau sebaliknya kemunduran, tergantung pada kemampuan dalam mengaktualisasikan potensi-potensinya”.

Pengertian tersebut mengartikan bahwa melalui keberadaan Pemuda Theravada Indonesia (Patria) yang ada di setiap wilayah, Pemuda Theravada Indonesia (Patria) mempunyai tugas sebagai pelestari Dhamma. Eksistensi dari Paemuda Theravada Indonesia (Patria) sangat berguna dalam menumbuhkan dan mempertahankan keyakinan remaja Buddhis dan umat Buddha pada ajaran-ajaran Sang Buddha. Remaja Buddhis atau umat Buddha di Kabupaten Temanggung sangat membutuhkan Eksistensi Pemuda Theravada Indonesia (Patria). Berdasarkan latar belakang tersebut penulis berminat untuk menggali lebih dalam mengenai "Eksistensi Pemuda Theravada Indonesia (Patria) Kabupaten Temanggung dalam Mempertahankan Keyakinan Remaja Buddhis".

Tujuan penelitian ini adalah 1) Untuk mengetahui Eksistensi Pemuda Theravada Indonesia (Patria) Kabupaten Temanggung dalam Mempertahankan Keyakinan Remaja Buddhis. 2) Untuk mengetahui faktor yang mempengaruhi keyakinan remaja Buddhis Kabupaten Temanggung.

Adapun teori-teori eksistensi yang penulis ambil dari beberapa ahli, yaitu sebagai berikut : 
a. Eksistensi adalah kata yang berasal dari bahasa latin yaitu existere yang memiliki arti muncul, ada, timbul, dan berada. Menurut Kamus Besar Bahasa Indonesia (2014: p.378) eksistensi sama halnya dengan keberadaan artinya eksistensi menjelaskan tentang penilaian ada atau tidak adanya pengaruh terhadap keberadaan seseorang tersebut. Eksistensi biasanya dijadikan sebagai acuan pembuktian diri bahwa kegiatan atau pekerjaan yang dilakukan seseorang dapat berguna dan mendapat nilai yang baik di mata orang lain.

b. Perkembangan seseorang dipengaruhi eksistensinya dalam kehidupan bermasyarakat. Eksistensi manusia berkaitan erat dengan hubungan sosial kemasyarakatan. Selaras dengan hal tersebut menurut Driyarkara dalam Suharno (2016: p.10) menjelaskan tentang sifat dasar eksistensi manusia adalah sebagai berikut:

"Pada hakikatnya manusia bukanlah makhluk yang berada sendirinya di dunia ini, karena itu hakekat manusia hanya dapat diketahui berkat hubungannya dan dilihat dalam hubungannya dengan: 1) sehat jasmani (hubungan ke bawah), 2) sesamanya (hubungan mendatar, horisontal), dan Tuhan (hubungan ke atas transendental)".

Berdasarkan pernyataan di atas dapat disimpulkan bahwa setiap manusia memiliki hubungan dengan sehatnya jasmani seseorang atau dapat dikatakan manusia berhubungan dengan dirinya sendiri. Selain itu eksistensi sifat dasar manusia berhubungan dengan sesama dan lingkungannya serta hubungannya dengan Tuhan. Kondisi tersebut dapat diartikan bahwa manusia yang memiliki sifat-sifat tersebut dapat dikatakan ada keberadaaanya. Sifat dasar manusia dalam eksistensinya sebagai makhluk sosial. Hal tersebut dikarenakan manusia sehat jasmani adalah orang yang mampu berinteraksi dengan lingkungan sesamanya. Hasil interaksi dengan lingkungan sebagai bentuk hubungan manusia dengan Tuhan Yang Maha Esa.

Organisasi berasal dari kata organ dalam bahasa Yunani yang artinya alat. Oleh karena itu dapat didefinisikan bahwa organisasi merupakan sebuah alat yang terdiri dari sekumpulan individu terhadap pembagian kerja kelompok dalam rangka mewujudkan tujuan yang telah diciptakan secara sistematis dan struktural, Fahmi (2013: pp.1-2). Siswanto dalam Endah (2011: p.25), organisasi dapat didefinisikan sebagai sekelompok orang yang saling berinteraksi dan bekerja sama untuk merealisasikan tujuan bersama. Berdasarkan pendapat Siswanto tersebut dapat diketahui bahwa organisasi adalah interaksi dari sekelompok orang yang bekerja sama dalam mencapai sebuah tujuan. Definisi yang sama juga dijelaskan Suharso \& Ana (2009: p.803) organisasi adalah kelompok kerjasama antara orang-orang yang diadakan untuk mencapai tujuan bersama.

Berdasarkan penjelasan di atas, dapat diketahui bahwa unsur terpenting dalam organisasi adalah interaksi dan kerjasama sekelompok orang dalam mencapai tujuan bersama. Hal ini juga berkaitan dengan ajaran hidup Buddha Gautama bahwa setelah Pangeran Siddhattha mencapai 
penerangan sempurna atau menjadi seorang Buddha, Sang Buddha telah membabarkan Dhamma kepada lima orang pertapa, diantaranya: Kondanna, Baddhiya, Vappa, Asaji, dan Mahanama. Kelima orang petapa ini setelah merenungkan khotbah Sang Buddha, mereka semua dapat membersihkan diri mereka dari segala kekotoran batin dan terbebas dari kemelekatan serta mencapai tingkat kesucian tertinggi yaitu Arahat, Widya. (1979: p.42).

Pemuda Theravada Indonesia (Patria) adalah sebuah organisasi sosial-keagamaan Buddha Theravada Indonesia yang bercorak kepemudaan. Pemuda Theravada Indonesia (Patria) merupakan organisasi Buddhis independen yang tidak terkait politik dalam melaksanakan kegiatan-kegiatannya, tetapi setiap pribadi anggota Patria berhak dan bebas menentukan hak politiknya.

Keyakinan adalah kepercayaan yang tidak berbelah lagi. Keyakinan dapat diartikan sebagai tekad yang tidak dapat terpisahkan dalam pribadi seseorang. Sama halnya dengan yang diungkapkan oleh Suhaimin (2015: p.10) keyakinan sebagai bentuk bahwa dirinya boleh mengendalikan kehidupannya dengan baik serta segala ujian/tantangan yang dihadapi dengan jayanya. Keyakinan yang telah diajarkan oleh Buddha yaitu sebagai kebenaran yang mutlak yang berlaku secara universal.

Remaja menurut Ansrori \& Ali (2012: p.9) dalam bahasa aslinya disebut adolescence, berasal dari bahasa latin adolescere yang artinya "tumbuh atau tumbuh untuk mencapai kematangan". Bangsa primitif dan orang-orang purbakala memandang masa puber dan masa remaja tidak berbeda dengan periode lain dalam rentang kehidupan. Anak dianggap sudah dewasa apabila sudah mampu mengadakan reproduksi. Seorang remaja yang tumbuh untuk mencapai kematangan sudah mampu mengadakan reproduksi didalam dirinya

\section{METODE PENELITIAN}

Penelitian ini menggunakan jenis penelitian kualitatif pendekatan deskriptif. Bogdan dan Taylor dalam Moleong (2007: p.4) mendefinisikan penelitian kualitatif sebagai prosedur penelitian yang menghasilkan data deskriptif berupa katakata tertulis atau lisan dari orang-orang dan perilaku yang diamati dari fenomena yang terjadi. Lebih lanjut Moleong (2007: p.11) mengemukakan bahwa penelitian deskriptif menekankan pada data berupa kata-kata, gambar, dan bukan angka-angka yang disebabkan oleh adanya penerapan metode kualitatif. Selain itu semua yang dikumpulkan berkemungkinan menjadi kunci terhadap apa yang sudah diteliti.

Tempat Penelitian ini dilaksanakan di Kabupaten Temanggung. Waktu pelaksanaan penelitian ini dilaksanakan pada bulan Juni sampai Agustus 2018.

Teknik pengumpulan data yang digunakan dalam penelitian ini adalah :

a. Wawancara adalah percakapan yang dilakukan oleh dua orang atau lebih dengan maksud tertentu. Dalam hal ini yang menjadi responden adalah ketua Patria, remaja Buddhis dan umat Buddha di Kabupaten Temanggung. Wawancara dilakukan pada tanggal 30 Juli 2018, dan 05, 10, 12, 19 Agustus 2018.

b. Observasi merupakan teknik pengumpulan data yang dilakukan peneliti dengan mengadakan pengamatan secara langsung atau tidak langsung terhadap 
gejal-gejala yang sedang berlangsung. Teknik ini digunakan peneliti untuk memperoleh gambaran mengenai kegiatan Patria di Kabupaten Temanggung. Observasi dilakukan pada tanggal 12 dan 19 Agustus 2018.

c. Dokumentasi merupakan metode yang digunakan untuk memperoleh data mengenai hal-hal yang diperlukan oleh peneliti. Teknik Dokumentasi dalam penelitian ini digunakan untuk mendapatkan informasi dari narasumber.

Dokumentasi juga digunakan untuk menyimpan data serta dapat digunakan oleh peneliti sebagai bukti bahwa informasi yang digunakan benar-benar valid seperti foto kegiatan Patria yang dilakukan oleh remaja Buddhis Kabupaten Temanggung.

Teknik Keabsahan data yang digunakan dalam penelitian ini adalah :

a. Triangulasi sumber digunakan untuk menguji kredibilitas data yang dilakukan dengan cara mengecek data yang telah diperoleh melalui beberapa sumber. Untuk menguji kredibilitas data tentang eksistensi Patria terkait dengan keyakinan remaja Buddhis, maka pengumpulan data dan pengujian data yang telah diperoleh di dapat dari wawancara dengan ketua Patria, remaja Buddhis, dan umat Buddha. Data dari ketiga sumber tersebut dideskripsikan, dikategorisasikan mana pandangan yang sama, yang berbeda, dan mana yang spesifik dari ketiga sumber tersebut. Berdasarkan pengertian triangulasi sumber, hal serupa peneliti melakukan pengecekan hasil wawancara yang didapatkan dan disimpulkan dari eksistensi Patria di Kabupaten Temanggung terkait dengan keyakinan remaja Buddhis.

b. Triangulasi teknik digunakan untuk menguji kredibilitas data yang dilakukan dengan cara mengecek data kepada sumber yang sama dengan teknik yang berbeda. Data yang diperoleh melalui wawancara, kemudian dicek dengan data observasi. Sesuai dengan pengertian tersebut, peneliti menggunakan triangulasi teknik untuk mengecek data yang diberikan oleh informan. Peneliti mengecek kembali data yang diberikan oleh para informan apakah sesuai dengan keadaan atau tidak. Triangulasi teknik dilakukan di rumah informan pada saat melakukan wawancara dan melakukan pengecekan kembali dengan melakukan pengamatan pada saat kegiatan berlangsung.

Teknik analisis data yang digunakan dalam penelitian ini mengacu pada konsep Milles \& Huberman dalam Moleong (2007: p.20) yaitu interaktif model yang mengklasifikasikan analisis data dalam tiga langkah:

a. Reduksi data (Data Reduction)

Data yang telah diperoleh dari lapangan, perlu diteliti lagi secara terperinci. Semakin lama penelitian, maka jumlah data akan semakin banyak, kompleks, dan rumit. Sehingga hal itu perlu dilakukan analisis data melalui reduksi data, yaitu kegiatan merangkum, memilih hal-hal pokok, memfokuskan pada hal-hal yang 
penting, mencari tema dan polanya, Sugiyono (2007: p.92).

b. Penyajian data (Display Data)

Setelah reduksi data telah dilakukan, yang selanjutnya adalah menyajikan data, cara ini digunakan untuk memudahkan dalam memahami apa yang terjadi, merencanakan kerja selanjutnya berdasarkan apa yang dipahami. Penyajian data merupakan sekumpulan informasi yang tersusun yang memberi kemungkinan adanya penarikan kesimpulan dan pengambilan tindakan. Informasi disini dapat berupa skema, tabel, matrik, grafik, dan jaringan kerja yang terkait dengan penelitian.

c. Penarikan kesimpulan (Verification)

Langkah yang terakhir adalah penarikan kesimpulan atau verification. Kesimpulan awal yang dikemukakan masih bersifat sementara dan akan berubah jika ditemukan bukti-bukti kuat yang mendukung pada tahap pengumpulan data berikutnya. Dan apabila kesimpulan yang dikemukakan pada tahap awal didukung oleh bukti-bukti yang valid dan konsisten saat peneliti kembali ke lapangan mengumpulkan data, maka kesimpulan yang dikemukakan merupakan kesimpulan yang kredibel.

\section{HASIL DAN PEMBAHASAN}

Hasil penelitian ini menunjukkan bahwa keyakinan remaja Buddhis dapat bertahan karena beberapa faktor yaitu, Niat (Cettana), Semangat (Viriya), Kesadaran (Sati). Dengan adanya niat dari remaja Buddhis, maka akan muncul kesadaran dan dari kesadaran akan tumbuh semangat dan keyakinan yang kuat sehingga hal itu mampu mempertahankan keyakinan remaja Buddhis. Sedangkan faktor yang menghambat adalah Rasa Malas, teman sebaya, faktor lingkungan, kurang aktifnya kegiatan Patria, dan kondisi. Adanya rasa malas dapat disebabkan oleh faktor intern dan ekstern. Faktor ekstern ini bisa dari faktor teman sebaya, lingkungan dan orang tua yang tidak mengizinkan mengikuti kegiatan-kegiatan Patria seperti Dhamma camp, Dhamma class yang biasanya dilaksanakan di luar daerah Temanggung. Selain itu karena kurang aktifnya kegiatan Patria dapat memicu malasnya remaja Buddhis untuk tidak hadir pada kegiatan Patria. Berdasarkan kondisi ini seharusnya eksistensi Patria lebih di tonjolkan dan mengadakan sosialisasi kepada remaja Buddhis.

Hal ini didukung dengan teori yang diungkapkan oleh Suhaimin (2015: p.10) keyakinan sebagai bentuk bahwa dirinya boleh mengendalikan kehidupannya dengan baik serta segala ujian/tantangan yang dihadapi dengan jayanya. Keyakinan yang telah diajarkan oleh Buddha yaitu sebagai kebenaran yang mutlak yang berlaku secara universal. Hal tersebut dikarenakan dapat direalisasikan melalui usaha-usaha tekun dan tekad yang kuat. Seseorang yang kuat dalam keyakinan tetapi lemah dalam kebijaksanaan akan memiliki keyakinan yang fanatik dan tanpa dasar.

\section{KESIMPULAN}

Berdasarkan hasil dan pembahasan penelitian, maka dapat disimpulkan sebagai berikut :

a. Eksistensi Pemuda Theravada Indonesia (Patria) Kabupaten Temanggung dalam Mempertahankan Keyakinan Remaja Buddhis masih belum maksimal. Fakta yang terjadi banyak remaja Buddhis yang 
malas pergi ke vihara, mengikuti kegiatan agama dan kegiatan Patria. Hal ini menyebabkan keyakinan remaja Buddhis pada Tri Ratna mengalami penurunan, sehingga akan berdampak pada perpindahan agama yang dilakukan oleh remaja Buddhis. Karena Patria merupakan motivator dan network atau jaringan penghubung dalam menggerakan remaja Buddhis untuk lebih aktif mengikuti kegiatan-kegiatan Patria dan kegiatan keagamaan lainnya sehingga hal ini mampu meningkatkan keyakinan remaja Buddhis. Adapun cara yang dilakukan oleh organisasi Patria dalam mempertahankan keyakinan remaja Buddhis yaitu dengan mengadakan sosialisasi, lebih mengaktifkan kegiatan Patria, bergabung dengan Patria kabupaten lain dalam acara keagamaan.

b. Faktor yang mempengaruhi Keyakinan remaja Buddhis kabupaten Temanggung yaitu, Niat (Cettana), Semangat (Viriya) dan Kesadaran (Sati). Dengan adanya niat dari remaja Buddhis, maka akan muncul kesadaran dan dari kesadaran akan tumbuh semangat dan keyakinan yang kuat sehingga hal itu mampu mempertahankan keyakinan remaja Buddhis. Sedangkan faktor yang menghambat adalah Rasa Malas, teman sebaya, faktor lingkungan, kurang aktifnya kegiatan Patria, dan kondisi individu remaja Buddhis. Adanya rasa malas dapat disebabkan oleh faktor intern dan ekstern. Faktor ekstern ini bisa dari faktor teman sebaya, lingkungan dan orang tua yang tidak mengizinkan mengikuti kegiatan-kegiatan Patria seperti Dhamma camp, Dhamma class yang biasanya dilaksanakan di luar daerah Temanggung. Selain itu karena kurang aktifnya kegiatan Patria dapat memicu malasnya remaja Buddhis untuk tidak hadir pada kegiatan Patria. Berdasarkan kondisi ini seharusnya eksistensi Patria lebih di tonjolkan dan mengadakan sosialisasi kepada remaja Buddhis.

\section{DAFTAR PUSTAKA}

Ansrori \& Ali. (2012). Psikologi Remaja. Jakarta: PT. Bumi Aksara.

Endah, T. (2011). Pengaruh Keaktifan Berorganisasi dan Kebiasaan Belajar Terhadap Prestasi Belajar Mahasiswa Jurusan Pendidikan Geografi Angkatan 2008 dan 2009 Universitas Negeri Yogyakarta. Skripsi Yogyakarta: Universitas Negeri Yogyakarta.

Fahmi, I. (2013). Perilaku Organisasi (Teori, Aplikasi, dan Kasus). Bandung: Alfabeta.

Moleong, L. J. (2007). Metodologi Penelitian Kualitatif. Bandung: Remaja Rosdakarya.

Sugiyono. (2007). Metode Penelitian Kuantitatif, Kualitatif dan $R \quad \& \quad D$. Bandung:Alfabeta.

Suhaimin, T. (2015). Keajaiban Keyakinan Diri. Ugmc. Bozland. Com.

Suharso \& Ana, R. (2009). Kamus Besar Bahasa Indonesia. Semarang: Widya Karya.

Suharso \& Ana, R. (2009). Kamus Besar Bahasa Indonesia. Semarang: Widya Karya. 
Nivedana - Jurnal Komunikasi \& Bahasa

Volume 1, No 1, Juli 2020

Tim Redaksi Kamus Besar Bahasa Indonesia Pusat Bahasa. (2014). Kamus Besar Bahasa Indonesia Pusat Bahasa. Jakarta: PT Gramedia Pustaka Utama.

Widya, D. (1979). Riwayat Hidup Buddha Gautama. Jakarta: Yayasan Dana Pendidikan Buddhis Nalanda.

Widya, D. K. (2010). Penuntun Berorganisasi. Jakarta: Dewan Pengurus Daerah Pemuda Theravada Indonesia.

Zaenal, A. (2007). Analisis Eksistensial. Jakarta: PT Raja Grafindo Persada. 